\title{
Potential of red mud as raw material for alternative binders in concrete
}

\author{
Ivana Vladić Kancir ${ }^{1}$, Asst. Prof. Marijana Serdar² \\ ${ }^{1}$ Sveučilište u Zagrebu, Građevinski fakultet, Zavod za materijale, ivana.vladic.kancir@grad.unizg.hr \\ ${ }^{2}$ Sveučilište u Zagrebu, Građevinski fakultet, Zavod za materijale, marijana.serdar@grad.unizg.hr
}

\begin{abstract}
Storage of large quantities of industrial by-products can pose a serious environmental problem. There is a growing need to recycle these industrial by-products, including red mud, in the construction industry, which is one of the largest consumers of raw materials. A preliminary study of the potential of red mud as a raw material for concrete is presented in this paper. Chemical composition of red mud, determined by X-ray fluorescence and particle size distribution by laser diffraction, is tested as part of its initial evaluation. The reactivity of red mud is evaluated by the R3 test method with isothermal calorimetry. The compressive strength test is carried out on a mortar sample in which $30 \%$ by weight of cement is replaced by red mud. Preliminary tests indicate that red mud can be used as raw material in alternative binders.
\end{abstract}

Key words: red mud, compressive strength, R3 test, supplementary cementitious material, concrete

\section{Potencijal crvenog mulja kao sirovine za alternativna veziva za beton}

\section{Sažetak}

Skladištenje velikih količina industrijskih nusproizvoda može predstavljati ozbiljan ekološki problem. Sve je veća potreba za recikliranjem tih industrijskih nusproizvoda, uključujući crveni mulj, u građevinskoj industriji koja je jedan od najvećih potrošača sirovina. Ovaj rad pokazuje preliminarno istraživanje potencijala crvenog mulja kao sirovine za beton. Kao dio početne procjene crvenog mulja prikazan je njegov kemijski sastav, određen rendgenskom fluorescencijom, i raspodjela veličine čestica, određena laserskom difrakcijom. Reaktivnost crvenog mulja procijenjena je metodom R3 baziranom na izotermalnoj kalorimetriji. Ispitivanje tlačne čvrstoće provedeno je na uzorku morta u kojem je 30\% mase cementa zamijenjeno crvenim muljem. Preliminarni rezultati pokazuju da se crveni mulj može koristiti kao sirovina u alternativnim vezivima.

Ključne riječi: crveni mulj, tlačna čvrstoća, $R 3$ ispitivanje, mineralni dodatci, beton 


\section{Introduction}

Due to an increased demand for housing caused by population growth, concrete consumption has increased to such an extent that it has become the second most frequently used material in the world after water [1]. It is estimated that the cement industry alone will be responsible for $24 \%$ of total global $\mathrm{CO}_{2}$ emissions by 2050 [2]. In order to meet people's need for urbanisation, while meeting European targets for protecting natural resources and reducing emissions, there is a strong motivation to develop more sustainable construction solutions with lower environmental impact, and in line with the seventh basic requirement for construction - the sustainable use of natural resources [3].

$\mathrm{CO}_{2}$ is emitted during production of Portland cement clinker in two ways, namely a) through the energy input required to heat the cement kiln and b) through the decarbonization of calcium carbonate $\left(\mathrm{CaCO}_{3}\right)$ [4]. The first case accounts for 40-50 $\%$ of emissions during production, while the chemical reaction of calcium carbonate releases accounts for the rest. Considering that the raw material in Ordinary Portland cement (OPC) consists mainly of $\mathrm{CaCO}_{3}$ (75 to $79 \%$ ) [4], the above-mentioned emissions can significantly be reduced by large-scale replacement of clinker with cement-like additives (SCM). Alternative materials that can be used in sustainable concrete structures are mainly industrial by-products in the form of finely crushed material that is added to the cement as partial replacement in order to improve certain properties and/or create some special properties [5].

Disposal of non-ferrous industrial and municipal solid waste has always been an important environmental issue. Red mud (RM) is a typical non-ferrous industrial solid waste [6]. RM is a bauxite residue from the Bayer process, which is used in alumina production. The Bayer process is the most important industrial process for refining bauxite to produce alumina (aluminium oxide). Bauxite, the main aluminium ore, contains only 30-54 \% alumina (alumina), $\mathrm{Al}_{2} \mathrm{O}_{3}$, while the rest is silica, iron oxides and titanium dioxide. Alumina must be purified before it can be refined into aluminium. In the Bayer process, bauxite is decomposed by washing with warm sodium hydroxide solution, $\mathrm{NaOH}$, at a temperature of $175^{\circ} \mathrm{C}$. This converts the alumina in the ore to sodium aluminate, $2 \mathrm{NaAl}(\mathrm{OH})_{4^{\prime}}$ according to equation (1):

$$
\mathrm{Al}_{2} \mathrm{O}_{3}+2 \mathrm{NaOH}+3 \mathrm{H}_{2} \mathrm{O} \rightarrow 2 \mathrm{NaAl}(\mathrm{OH})_{4}
$$

Other bauxite components can not be dissolved. The solution is cleaned by filtration to remove solid impurities. The mixture of solid impurities is called red mud (RM) and is a problem for disposal [7]. In addition, open land disposal of RM contaminates the environment, causing ecological imbalance. Annual emissions of red mud are estimated at more than 70 million tons worldwide [8]. 


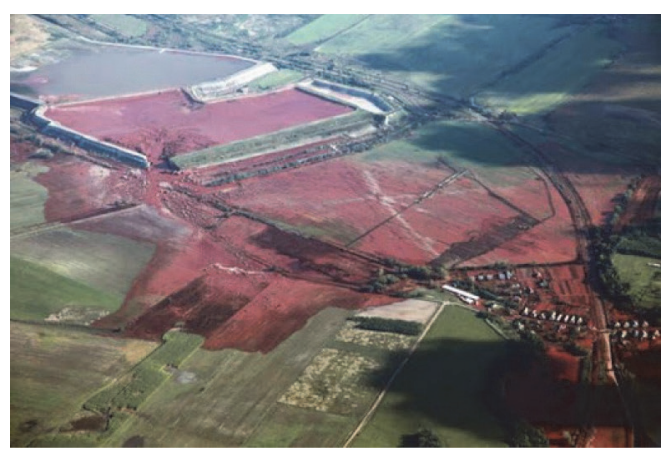

Figure 1. Red mud landfill [9]

In Southeast Europe, there are several active aluminium processing plants and red mud landfills, which remain at the plant site even after plant closure. In Croatia, the inactive Jadral plant near Obrovac has been closed since 1982, but a $720000 \mathrm{~m}^{3}$ landfill is still there. In Montenegro, Uniprom KAP is an aluminium plant that produces over 120,000 tons of alumina per year. Its waste is disposed of in two large landfills nearby, each of which contains over four million tons of waste. There are also two red mud landfills in Bosnia and Herzegovina at Birač near Zvornik and at Dobro Selo near Mostar. The landfill in Dobro Selo contains over ten million tons of waste and represents a potential threat to the environment.

Chemical composition of RM depends on the bauxite ore and the refining process. The most important chemical compounds in $\mathrm{RM}$ are iron oxide $\left(\mathrm{Fe}_{2} \mathrm{O}_{3}\right)$, aluminium oxide $\left(\mathrm{Al}_{2} \mathrm{O}_{3}\right)$, sodium oxide $\left(\mathrm{Na}_{2} \mathrm{O}\right)$, silicon dioxide $\left(\mathrm{SiO}_{2}\right)$, titanium oxide $\left(\mathrm{Ti}_{2} \mathrm{O}\right)$, and calcium oxide ( $\mathrm{CaO})[10]$. RM is also highly alkaline in nature. Conventional methods for the disposal of red mud at a landfill near the factory were simple and inexpensive. However, potential impact on the surrounding groundwater and environment, and difficulties associated with surface remediation, have led to significant changes in waste management practices. The use of RM has been limited due to its high iron content, presence of alkalis, and very small particle size.

Studies have been carried out on the use of RM as raw material in various industries, such as in brick industry, ceramic tile production, chemical industry and in the production of metal absorbents [10]. RM is an alkaline, cement-like material and can be used as a partial substitute for cement to reduce $\mathrm{CO}_{2}$ emissions and soil pollution through the disposal of RM [11]. In addition, RM has high alumina and silica content [12]. When cement is hydrated, calcium hydroxide reacts with silica in the RM cement, thus increasing the strength of the concrete [13]. The presence of aluminates and ferrites increases the reactivity of silica in cementitious materials [14]. Senff et al [15] and Tang et al [16] prepared cement mortar in which up to $50 \%$ of cement was replaced with RM. They reported that the compressive strength and tensile strength decreased with an increase in RM content. Another study by Ribeiro 
et al. [17] revealed that an increase in the amount of RM used to replace cement shortened the setting time and reduced pozzolan reactivity, which in turn reduced the strength of cement mortar. On the other hand, it has been reported in literature that RM can improve resistance of concrete to chloride penetration due to its filling effect and high alkalinity [18]. Iron oxide and aluminium oxide are predominant chemical compounds in RM, and they potentially improve the surface layer that protects reinforcement from carbonation and chloride ion attack [18]. The use of RM in alkali activated materials (AAM) has also been investigated by some researchers [26-29]. In most cases, it was used in combination with other aluminium silicate minerals such as metakaolin and fly ash [19]. It has been observed that the AAM red mud exhibits reasonable compressive strength [19]. In addition, alkali activation makes it possible to significantly increase the quantity of red mud incorporated in cement and concrete without impairing physicomechanical properties of cement and concrete [20].

The aim of this research is to evaluate basic properties of red mud from a landfill in Bosnia and Herzegovina as part of a more systematic approach to screening by-products and waste streams as potential raw materials in concrete. Previous research has shown that red mud from Dobro Selo, Mostar, Bosnia and Herzegovina, reduces mechanical properties of concrete but improves its durability properties, especially its resistance to chloride diffusion. The same red mud source was used for this research and, as a first step in the research, chemical and physical properties of red mud, as well as its reactivity, were analysed by determining heat development with calorimetry, and strength development.

\section{Materials and methods}

\subsection{Materials}

Red mud (RM) from Dobro Selo near Mostar, Bosnia and Herzegovina, was evaluated in this study. In addition, fly ash from Tuzla and cement CEM I $42.5 \mathrm{R}$ were used for comparison purposes. Both red mud and fly ash were first dried in an oven for $24 \pm 2 \mathrm{~h}$ at $60 \pm 5^{\circ} \mathrm{C}$ and then ground in a disc mill for 2 minutes.
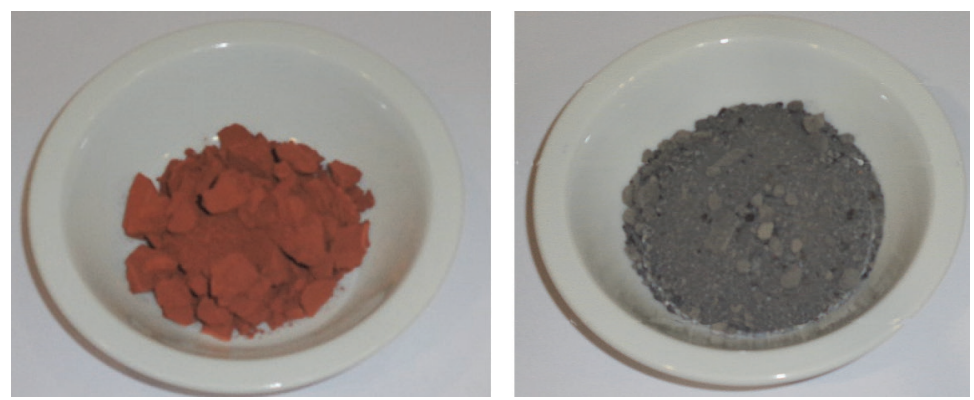

Figure 2. Dried samples of red mud and fly ash 


\subsection{Methods}

\subsubsection{Chemical composition}

Chemical composition of the materials was determined by X-ray fluorescence (XRF) in cooperation with the accredited laboratory "HEP-proizvodnja d.o.o.", Central Chemical-Technological Laboratory, Zagreb. The materials were tested in two conditions: "as received" and after being dried at $110^{\circ} \mathrm{C}$. The difference in the results depends on moisture content of the material. Relevant results presented here are those obtained in dry condition.

\subsubsection{Particle size distribution}

Particle size distribution (PSD) was tested using the laser diffraction method with the MASTERSIZER instrument (Malner instruments) at EPFL Federal Institute in Lausanne, Switzerland. The test was performed according to the guidelines [22]. Before the test, the sample was dispersed in a specific solvent. The prepared liquid was dispersed in an ultrasonic bath for 15 minutes and then placed on a magnetic stirrer until the room temperature was reached. A laser diffraction test was then performed.

\subsubsection{Reactivity by calorimetry}

The R3 test [24], developed for the RILEM TC-267 committee, was used to determine reactivity of red mud and fly ash. This was carried out at $40{ }^{\circ} \mathrm{C}$ by isothermal calorimetry, and it involved determination of the total release of hydration heat from the paste composed of the SCMs, for 7 days. Before the test, SCMs and dry reagents were weighed, mixed and held at $40 \pm 2{ }^{\circ} \mathrm{C}$ for $24 \mathrm{~h}$. The formulation of solid blends relies on the ratio of $\mathrm{Ca}(\mathrm{OH}) 2 / \mathrm{SCM}$ and $\mathrm{CaCO}_{3} / \mathrm{SCM}$ of 3 and $1 / 2$, respectively. In addition, an alkaline solution $3 \mathrm{M}$ of $\mathrm{K}$ was prepared with $\mathrm{KOH}$ and $\mathrm{K}_{2} \mathrm{SO}_{4}$. The pastes with red mud and fly ash were prepared in a high shear mixer at $1600 \pm 50$ rpm and mixed for 2 minutes until a homogeneous paste was obtained. The pastes were immediately poured into a glass vial and placed in the isothermal calorimeter. The cumulative heat release acquired was given per g SCM. The corresponding results are shown in Figure 6.

\subsubsection{Evolution of compressive strength}

Standard mortars were cast according to HRN EN 196-1 [23] to determine strength development of the blends. Mortar samples were prepared with CEM 1 45.2 R, and $30 \%$ of the cement mass was replaced by red mud and fly ash. The water-binder 
ratio was constant, i.e. 0.5. The standardized sand was used as aggregate and there was no need for water adjustment. After casting, 40 × 40 × $160 \mathrm{~mm}$ samples were covered with plastic foil and kept for $24 \mathrm{~h}$ under laboratory conditions. After demoulding, the samples were cured in a damp chamber until the test time. The compressive strength test was determined on 2 prisms after 2,7 , and 28 days of curing.

\section{Results}

\subsection{Characterization of red mud}

Table 1 shows chemical analysis of cement CEM I $42.5 \mathrm{R}$, red mud (RM), and fly ash (FA). The main RM constituents are $\mathrm{Fe}_{2} \mathrm{O}_{3}, \mathrm{SiO}_{2}$ and $\mathrm{Al}_{2} \mathrm{O}_{3}$, which account for about $75 \%$ of the total composition. Compared to fly ash, red mud has a lower content of silicon dioxide and a higher content of iron oxides. Furthermore, red mud has a significantly higher content of $\mathrm{Na}_{2} \mathrm{O}(7.23 \%$ compared to $0.26 \%$ in fly ash) and a lower content of $\mathrm{SO}_{3}(0.24 \%$ compared to $1.48 \%$ in fly ash).

Table 1. Chemical composition of red mud, fly ash and cement

\begin{tabular}{|c|c|c|c|}
\hline Constituents & Red mud & Fly ash & CEM I 42,5 R \\
\hline $\mathrm{P}_{2} \mathrm{O}_{5}$ & 0.47 & 0.36 & \\
\hline $\mathrm{Na}_{2} \mathrm{O}$ & 7.23 & 0.26 & \\
\hline $\mathrm{K}_{2} \mathrm{O}$ & 0.18 & 1.51 & \\
\hline $\mathrm{CaO}$ & 9.96 & 11.52 & 64.04 \\
\hline $\mathrm{MgO}$ & 0.61 & 2.78 & 1.83 \\
\hline $\mathrm{Al}_{2} \mathrm{O}_{3}$ & 16.94 & 19.11 & 4.86 \\
\hline $\mathrm{TiO}_{2}$ & 4.13 & 0.52 & \\
\hline $\mathrm{Fe}_{2} \mathrm{O}_{3}$ & 37.88 & 9.05 & 2.94 \\
\hline $\mathrm{SiO}_{2}$ & 21.95 & 53.28 & 19.32 \\
\hline $\mathrm{MnO}$ & 0.43 & 0.13 & \\
\hline $\mathrm{SO}_{3}$ & 0.24 & 1.48 & 2.75 \\
\hline & & & \\
\hline
\end{tabular}

\subsection{Particle size distribution}

The particle size distribution of RM is shown in Figure 3. Red mud particles range from 0,05 to $65 \mu \mathrm{m}$ in size. The highest number of particles is in the range of $0,1-1$ $\mu \mathrm{m}$. Compared to fly ash samples and Portland cement samples, where most particles are between 1 and $100 \mu \mathrm{m}, \mathrm{RM}$ particles are finer. 


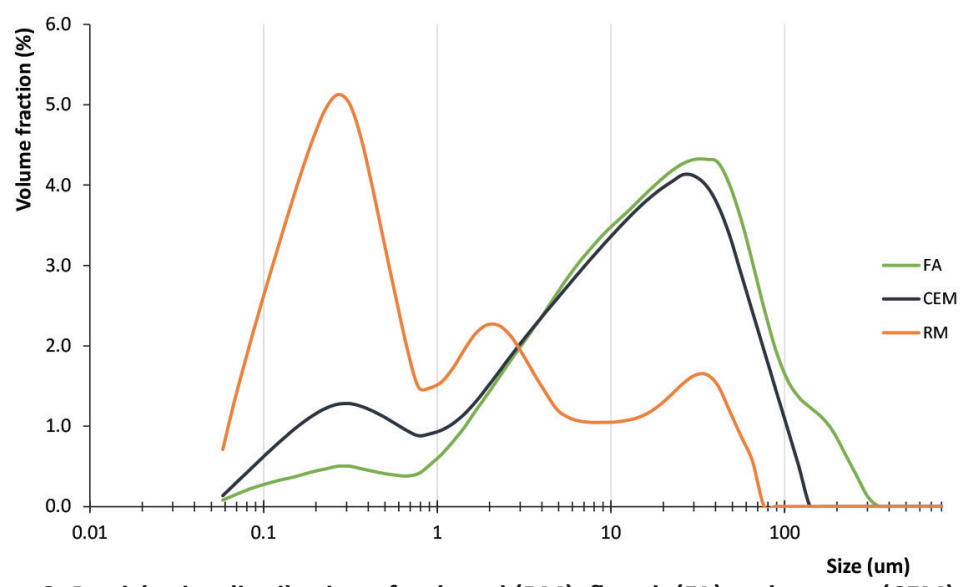

Figure 3. Particle size distribution of red mud (RM), fly ash (FA) and cement (CEM)

\subsection{Mechanical properties of mortar samples}

Compressive strength results are shown in Figure 4 . A mixture with $30 \%$ red mud (RM) showed lower compressive strength results than the OPC mortar after 28 days. However, a rapid increase in strength can be observed after 2 days for the sample with RM. The fly ash sample initially exhibited a lower compressive strength than the RM sample, but the fly ash sample strength was higher after 7 and 28 days.

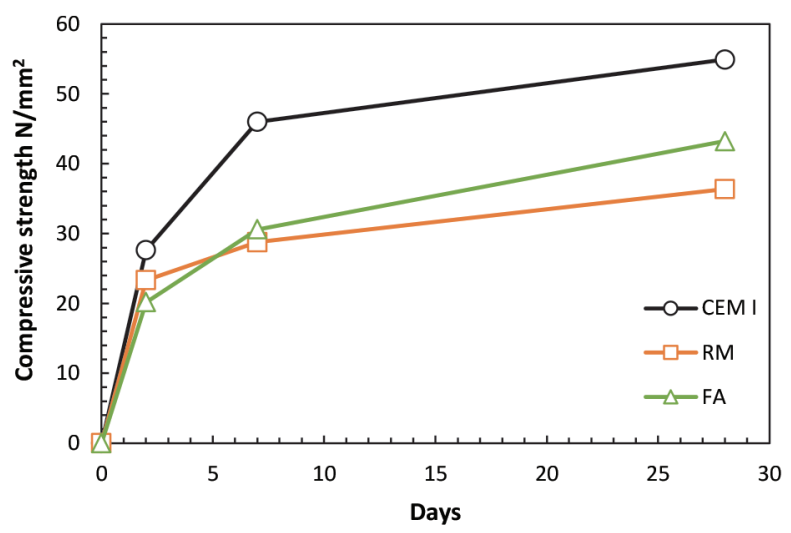

Figure 4. Compressive strength results for mortar samples with cement (CEM I), $30 \%$ of red mud (RM) and $30 \%$ of fly ash (FA)

This difference in strength increase is particularly evident when looking at relative compressive strength values in Figure 5 . The relative strength is defined as the ratio 
of strength results obtained from the mixtures to compressive strength results of the OPC mortar sample.

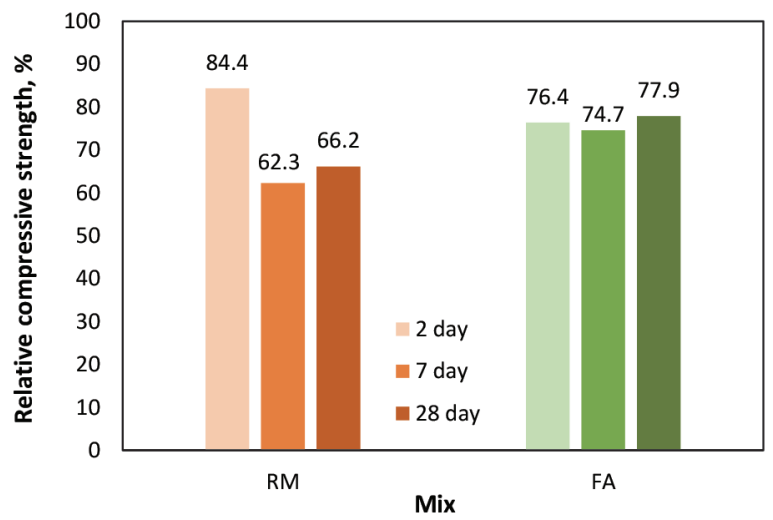

Figure 5.Compressive strength of mortar with $30 \%$ replacement by red mud (RM) and fly ash (FA) relative to mortar with cement

\subsection{Pozzolanic reactivity of red mud}

Figure 6 shows the total heat release during the R3 test performed on red mud and fly ash. According to the R3 test [23], the amount of heat can be used to assess the reactivity of SCMs. During the first 5 hours, the red mud sample showed a higher heat release, indicating a fast initial reaction. Compared to red mud, fly ash showed a slower initial reaction, but a higher long-term reactivity. These results are in strong agreement with compressive strength results.

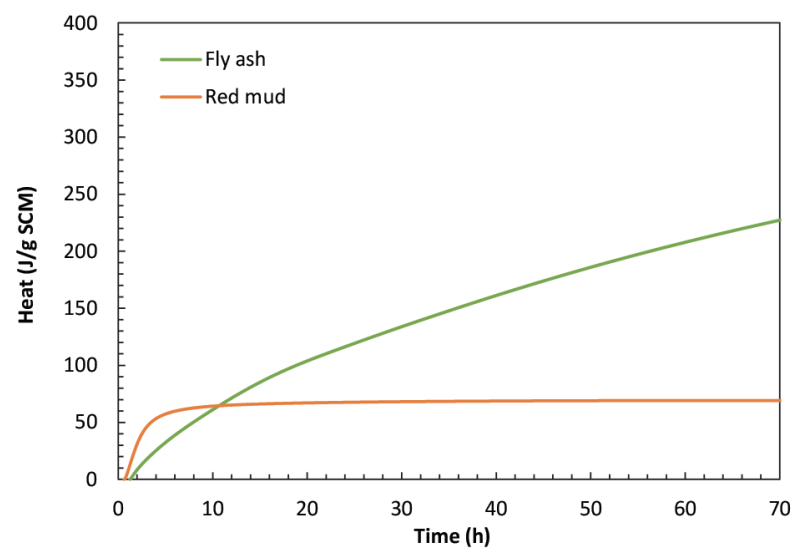

Figure 6. Results obtained by heat release measurement via R3 test using isothermal calorimetry 


\section{Conclusion and further research}

The red mud used in this research is characterised as a very fine powder consisting mainly of $\mathrm{Fe}_{2} \mathrm{O}_{3}, \mathrm{SiO}_{2}$ and $\mathrm{Al}_{2} \mathrm{O}_{3}$, which account for about $75 \%$ of its total composition. A large amount of alkalis is also characteristic of this waste material. The largest proportion of particles is in the range of $0.1-1 \mu \mathrm{m}$. Both the heat development and the compressive strength development showed that red mud reacts very quickly during the first few hours, and that later on it has low reactivity, especially compared to fly ash.

Based on the presented analysis, it can be concluded that the red mud used in this research has a potential as a raw material for concrete production. Even though strength tests show lower values, due to the large number of fine particles, red mud could potentially improve durability properties of concrete and ensure the filling of fine pores. Further research, which is to consider high levels of alumina and silica and high alkalinity, will be focused at developing alkali-activated binders based on red mud. In addition to durability aspect, possible radioactivity of red mud will be investigated in further research, which might narrow its potential for use in construction industry.

\section{Acknowledgement}

The research presented in the paper is part of a scientific project "Alternative binders for concrete: understanding the microstructure to predict durability, ABC" (UIP05-2017-4767), funded by Croatian Science Foundation.

\section{References}

[1] World Business Council for Sustainable Development, Cement Industry Energy and CO2 Performance - Getting the Numbers Right, 2009.

[2] J. L. Provis, Green concrete or red herring? - Future of alkali-activated materials, Advences in Applied. Ceramics, vol. 113, no. 8, pp. 472-477, 2014.

[3] E. Commission, Regulation of the European Parliament and of the Council, vol. 1, no. 2011. pp. 1-119, 2011.

[4] K. L. Scrivener and A. Nonat, Hydration of cementitious materials, present and future, Cement and Concrete Research, vol. 41, no. 7, pp. 651-665, Jul. 2011.

[5] M. Serdar, D. Bjegovic, N. Stirmer, and I. Banjad Pecur, Alternative binders for concrete: opportunities and challenges, in Scientific Symposium Future Trends in Civil Engineering, no. Zagreb, October 2019, pp. 199-218. 
[6] Y. Li, X. Min, Y. Ke, D. Liu, and C. Tang, Preparation of red mud-based geopolymer materials from MSWI fly ash and red mud by mechanical activation, Waste Manag., vol. 83, pp. 202-208, 2019.

[7] Rusković, N. (2013) Mogućnosti primjene crvenog mulja u betonskoj industriji. Diplomski rad.Zagreb: Sveučilište u Zagrebu, Građevinski fakultet

[8] H. Geng, J., Zhou, M., Zhang, T., Wang, W., Wang, T., Zhou, X., Wang, X., Hou, Preparation of blended geopolymer from red mud and coal gangue with mechanical co-grinding preactivation. Materials and Structures 50, 109., 2017

[9] Deset milijuna tona crvenog mulja kod Mostara, http://m.pogled.ba/clanak/desetmilijuna-tona-crvenog-mulja-kod-mostara/34842.

[10] C. Venkatesh, N. Ruben, M. Sri, and R. Chand, Red mud as an additive in concrete: comprehensive characterization, Journal of the Korean Ceramic Society , 2020.

[11] M. Abdel-Raheem, L.M. Gómez Santana, M.A. Piñeiro Cordava, B.Olazaran Martinez Uses of red mud as a construction materia, pp. 388-399, 2017.

[12] P. C. Taylor, Curing concrete, 2014.

[13] C. Venkatesh, R. Nerella, and M. Sri Rama Chand, Comparison of mechanical and durability properties of treated and untreated red mud concrete, Mater. Today Proc., vol. 27, pp. 284-287, 2020.

[14] G. R. Kumar, M.S.R. Chand, P.R. Kumar, P.S.N.R. Giri, Performance and microstructure characteristics of self-curing selfcompacting concrete, Adv. Cem. Res, vol. 30, no. 10, pp. 451-468, 2018.

[15] L. Senff, D. Hotza, and J. a. Labrincha, Effect of red mud addition on the rheological behaviour and on hardened state characteristics of cement mortars, Constr. Build. Mater., vol. 25, no. 1, pp. 163-170, Jan. 2011.

[16] H. C. W. Tang, Z. Wang, Y. Liu, Influence of red mud on fresh and hardened properties of self-compacting concrete, Constr. Build. Mater, pp. 178,288-300, 2018.

[17] D. V. Ribeiro, J.A. Labrincha,M.R.Morelli Potential use of natural red mud as pozzolan for Portland cement, Materials Research pp. 60-66, 2011.

[18] D. V. Ribeiro, J.A. Labrincha, M.R. Morelli Effect of the addition of red mud on the corrosion parameters of reinforced concrete, Materials Research pp. 124-133, 2012.

[19] A. Kumar and S. Kumar, Development of paving blocks from synergistic use of red mud and fly ash using geopolymerization, Construction and Building Materials., 38, pp. 865871, 2013.

[20] P. Krivenko et al., Development of alkali activated cements and concrete mixture design with high volumes of red mud, Construction and Building Materials., vol. 151, pp. 819826, 2017. 
[21] M. Serdar, I. Biljecki, and D. Bjegovic, High-Performance Concrete Incorporating Locally Available Industrial By-Products, Journal of Materials in Civil Engineering, vol. 29, no. 3, pp. 1-8, 2017.

[22] B. Lothenbach, K. Scrivener, and R. D. Hooton, Supplementary cementitious materials, Cement and Concrete Research, vol. 41, no. 12, pp. 1244-1256, Dec. 2011.

[23] "European Committee for Standardization (CEN), EN 196-1:2016 Methods of testing cement - Part 1: Determination of strength.

[24] F. Avet, R. Snellings, A. Alujas Diaz, M. Ben Haha, and K. Scrivener, Development of a new rapid, relevant and reliable (R3) test method to evaluate the pozzolanic reactivity of calcined kaolinitic clays, Cement and Concrete Research, vol. 85, pp. 1-11, 2016. 